\title{
Girls' Gymnastics in the Service of the Nation: Educationalisation, Gender and Swedish Gymnastics in the Mid-Nineteenth Century
}

\author{
Johannes Westberg
}

\begin{abstract}
In the nineteenth and early twentieth century, Swedish gymnastics won a large following across the world. Employing the concepts of educationalisation and gender, I will explore how the physical education of girls was conceptualised and justified in the Swedish system during the latter half of the nineteenth century. Focusing on the publications of Anton Santesson (1825-1892), who was one of the main authors on girls' gymnastics in Sweden, I will show how girls' gymnastics was conceptualised as a response to a social, cultural and physical crisis, which was perceived as partly stemming from the detrimental effects of education on girls' bodies and minds. Girls' gymnastics was thus construed as vital to the future of the Swedish nation. While men and manliness remained fundamental to the strength of the nation, girls' gymnastics was vital to women's rearing of boys and thus instrumental to the development of masculinity in men.
\end{abstract}

Keywords $\bullet$ Swedish gymnastics, educationalisation, gender, nation building, history of education

\section{Introduction}

Alongside sloyd, Swedish gymnastics (The Swedish system/Lingian gymnastics) is probably Sweden's most significant contribution to the history of education. Invented by Pehr Henrik Ling (1776-1839), and refined by his followers, the purpose of this system of gymnastics was to systematically exercise each part of the human body. While mostly featuring freestanding exercises, it also involved some apparatus work, and was characterised by a high degree of formalisation. Promoting manliness and nation building, the Swedish system soon won a significant following across the world. ${ }^{1}$

1 Regarding the dissemination of the Swedish system, see, e.g., Anne Bloomfield, "Martina BergmanOsterberg (1849-1915): Creating a Professional Role for Women in Physical Training," History of Education 34, no. 5 (2005); N. Bazoge et al., "Promoting the Swedish Method of Physical Education Throughout France for the Benefit of Public Health (1868-1954)," Scandinavian Journal of Medicine \& Science in Sports 23, no. 2 (2013); Patricia Vertinsky, The Eternally Wounded Woman: Women, Doctors, and Exercise in the late Nineteenth Century (Urbana: University of Illinois Press, 1994), 144; Natalie Barker-Ruchti, "'Stride Jump - Begin!': Swedish Gymnastics in Victorian England," Sporting Traditions 22, no. 2 (2006); Theirry Terret and Leomar Tesche, "French Gymnastics in Brazil: Dissemination, Diffusion and Relocalization," in Gymnastics: A Transatlantic Movement, ed. Gertrud Pfister (London: Routledge, 2014), 96; Henrik Meinander, Towards a Bourgeois Manhood: Boys' Physical Education in Nordic Secondary Schools 1880-1940 (Helsinki: Societas scientiarum Fennica, 1994), 36-38. The role of Ling gymnastics in Switzerland is discussed by Ingrid Brühwiler in her contribution to this special issue.

Johannes Westberg is Professor in Education at the School of Humanities, Education and Social Sciences, Örebro University, Sweden.

Email: johannes.westberg@oru.se

In order to maintain the integrity of the peer review process, senior editor Henrik Åström Elmersjö and associate professor Esbjörn Larsson has mediated the contacts between the author (who is one of the editors of this issue) and the reviewers of this article. 
Although, at its core, Swedish gymnastics was about manliness and masculinity, gymnastics targeting girls and women was introduced during the nineteenth century. Drawing on the concept of educationalisation, which highlights how various social, cultural and economic problems have been interpreted as educational problems, this article explores how the emerging girls' gymnastics in Sweden was conceptualised and justified in relation to the development of the Swedish nation and the minds and bodies of individual women. What where the individual and societal ills that girls' gymnastics was supposed to remedy, and how was it supposed to accomplish this aim? Using Anton Santesson's writings on gymnastics and girls' gymnastics published in the 1850 s and 1860 s as an empirical starting point, I will show how a wide range of evidence, from statistics to general impressions and individual examples, were used to motivate the implementation of girls' gymnastics. I will also delineate how a number of ideas and beliefs, including diverse notions of women's health, were used to conceptualise girls' physical education as fundamental to the strength of the Swedish nation, and as a response to the modernisation of society. Thus, I will delve deeper into how the main challenge of girls' gymnastics-how to make girls and young women eligible for gymnastics originally created for menwas solved.

\section{Political rationality, educationalisation and gender}

The theoretical framework of this article is inspired by the studies of governmentality carried out by Michel Foucault and eminent scholars such as Nikolas Rose, Peter Miller and Mitchell Dean. These studies draw attention to certain kinds of discourses and practices that mark the attempts (by both state and non-state agencies) to govern the health and wealth of populations that have proliferated since the eighteenth century. ${ }^{2}$ In analysing the aims and practices of girls' gymnastics, I am primarily interested in the political rationality of girls' gymnastics, that is the thinking, dreaming and planning that is required when aspiring to govern a population. More specifically, this concept enables me to focus on how girls' gymnastics was conceptualised and justified using theories, notions, various kinds of evidence and ways of reasoning. I am in that respect interested in what may be described as the intellectual machinery that was used to envision gymnastics and its impact on individuals and society. ${ }^{3}$

Exploring the political rationality of gymnastics, I will pay particular attention to how this governmentality of gymnastics was marked by the process of educationalisation. The concept of educationalisation sheds light upon how girls' gymnastics was related to problematics of varying kinds. As Nikolas Rose and Peter Miller noted, governing is a problematising activity linked to issues that need to be solved, failings that must be rectified and ills that must be cured. It is by the constant act of identifying such issues - whether pertaining to the morals of the population, the structure of the industry or the state of economy - that government agencies, doctors, businessmen, or philanthropists are able to formulate governmental programmes. ${ }^{4}$

2 Nikolas Rose and Peter Miller, "Political Power Beyond the State: Problematics of Government," British Journal of Sociology 43, no. 2 (1992), 174-75. For a presentation of governmentality that places it within a wider concept, see Mitchell Dean, Governmentality: Power and Rule in Modern Society (London: Sage, 2010), 1-12, 17-30.

3 Rose and Miller (1992), 175, 182.

4 Rose and Miller (1992), 180-81. 
In this context, the term "educationalisation" refers to the process through which various kinds of problems became interpreted as educational issues. As a result, in the discourses of the twentieth and twenty-first century, the perception of education as a solution to a wide variety of social, economic, cultural and moral problems has become an almost compulsive reflex. Whether debating road safety, obesity or alcohol abuse, education is commonly cited as the answer. Thus, schools are not only deemed responsible for presenting children with knowledge, but are also given the task of strengthening the economy and producing democratic citizens who eat healthily, make sound economic decisions and practice safe sex. ${ }^{5}$ When this reflex or discursive mechanism became established during the latter half of the eighteenth century and the first half of the nineteenth century, gymnastics was integrated into this educationalisation of the world. Swedish gymnastics was, for example, promoted as a response to the (perceived) detrimental effects of modern society, the crisis of manliness, and as a disciplinary method for creating national citizens and strengthening the nation state. ${ }^{6}$ In this article, I will examine this educationalisation process in the context of girls' gymnastics.

In exploring how girls' gymnastics was conceptualised as a response to the issues facing nineteenth-century Sweden, it is vital to consider the concept of gender. In this article, gender is understood as a social construct that is always created, maintained or contested through practices, words and perceptions. The concept of gender thus draws attention to the various ways that gender is constructed at social, economic, cultural, discursive and political levels. ${ }^{7}$ Here, gender is employed to highlight how aims and justifications for gymnastics produced and reproduced discourses on gender differences. In the analyses presented in this article, the notion of the relational character of gender has been particularly useful, since it highlights how gender is always a matter of the relation between masculinity and femininity. In that respect, this study is also influenced by extant works highlighting the multifaceted relationships between gender and nation building projects. ${ }^{8}$

Girls' gymnastics is a vital research object for several reasons. The historiography of Swedish physical education has exhibited an impressive growth during the last decades, investigating for example physical education as a popular movement; Ling gymnastics as a project of masculinity; body, class and gender in twentieth centu-

5 Daniel Tröhler, Pestalozzi and the Educationalization of the World (Basingstoke: Palgrave Macmillan, 2013), 2-4; Paul Smeyers and Marc Depaepe, eds., Educational Research: The Educationalization of Social Problems (Dordrecht: Springer Netherlands, 2008). For a recent analysis of educationalisation in the case of English teaching, see Jory Brass, "English Teaching and the Educationalisation of Social Problems in the United States, 1894-1918," Paedagogica Historica 52, no. 3 (2016).

6 See, e.g., Jens Ljunggren, Kroppens bildning: Linggymnastikens manlighetsprojekt 1790-1914 (Eslöv: Symposion, 1999).

7 For a general discussion on the concept of gender that has influenced this study, see Joan W. Scott, "Gender: A Useful Category of Historical Analysis," The American Historical Review 91, no. 5 (1986): 1053-75.

8 See, e.g., Ida Blom, Karen Hagemann and Catherine Hall, eds., Gendered Nations: Nationalisms and Gender Order in the Long Nineteenth Century (Oxford: Berg, 2000). For definitions of gender used in studies of physical education, see, e.g., Gertrud Pfister, "Women in Sport - Gender Relations and Future Perspectives," Sport in Society 13, no. 2 (2010), 235-36; Suzanne Lundvall, "Gender Dynamics in the Making and Breaking of a Female PETE Culture in Sweden," in The Female Tradition in Physical Education: 'Women First' Reconsidered, ed. David Kirk and Patricia Vertinsky (London: Routledge, 2016), 153-54. 
ry physical education; and the careers of female physical educators. ${ }^{9}$ Despite this proliferation of research, the emergence of girls' and women's gymnastics remains relatively under-studied. The relative neglect of how girls' gymnastics was conceptualized and justified is also a feature of analyses focusing on the reception of Swedish gymnastics abroad, which merely touch upon this topic. Instead, such studies focuses other issues, such as the introduction of Swedish gymnastics in Victorian England, or the pioneering work of Martina Bergman-Osterberg. ${ }^{10}$

This article contributes to these strands of research by delving deeper into the theories, notions and various kinds of evidence that underpinned girls' gymnastics in Sweden. In addition, this article will contribute to a wider research field on girls' and women's gymnastics, including the research conducted by Sheila Fletcher and Ann Chisholm. Fletcher shows, for example, how women's gymnastics was promoted, using the ideology of Social Darwinism, as a response to the perceived demands created by the Boer War and the British rivalry with Germany. ${ }^{11}$ Likewise, Chisholm uncovers how notions of Republican motherhood legitimated gymnastics, and how notions of girls' poor health and the workings of the female body in terms of dyspepsia, constipation and gravity were used to conceptualise physical education's impact on women and the American society. ${ }^{12}$ Apart from presenting the first in-depth study of Anton Santesson's visions of girls' gymnastics, this article contributes to this line of research through a further investigation into the discursive work required to justify the introduction of girls' gymnastics.

\section{The history of Swedish gymnastics}

In Sweden, gymnastics became a subject of interest during the early nineteenth century. Although physical education had been a recurrent topic of academic debate in Sweden-dealt with in a number of dissertations on physical exercises (e.g., Dissertation Gradualis de Exercities Corporis, 1764; Gymnastica Graecorum ex Pindaro illustrate, 1773) and talks by esteemed academics such as Linnaeus - physical education became more widely discussed in the early nineteenth century by educatio-

9 Jan Lindroth, Idrottens väg till folkrörelse: Studier i svensk idrottsrörelse till 1915 (Uppsala: Uppsala universitet, 1974); Henrik Sandblad, Olympia och Valhalla: Idéhistoriska aspekter av den moderna idrottsrörelsens framväxt (Stockholm: Almqvist \& Wiksell international, 1985); Ljunggren (1999); Pia Lundquist Wanneberg, Kroppens medborgarfostran: Kropp, klass och genus i skolans fysiska fostran 1919-1962 (Stockholm: Stockholm universitet, 2004); Barbro Carli, The Making and Breaking of a Female Culture: The History of Swedish physical Education 'in a Different Voice' (Göteborg: Göteborgs universitet, 2004); Claes Annerstedt, Skolgymnastikens utveckling i Sverige (Göteborg: Göteborgs universitet, 1989); Leif Yttergren and Hans Bolling, "Kvinnor, karriär och famili: En studie av svenska kvinnliga gymnastikdirektörers yrkeskarriärer och livsöden kring sekelskiftet 1900," Historisk tidskrift 136, no. 2 (2016).

10 Bloomfield (2005); Barker-Ruchti (2006). See also, e.g., Else Trangback, "Discipline and Emancipation Through Sport," Scandinavian Journal of History 21, no. 2 (1996).

11 Sheila Fletcher, Women First: The Female Tradition in English Physical Education, 1880-1980 (London: Athlone, 1984), 27.

12 Ann Chisholm, "Gymnastics and the Reconstitution of Republican Motherhood among True Women of Civic Virtue, 1830-1870," The International Journal of the History of Sport 23, no. 8 (2006), 1279-83, 1288; Ann Chisholm, "Incarnations and Practices of Feminine Rectitude: Nineteenth-Century Gymnastics for U.S. Women," Journal of Social History 38, no. 3 (2005), 740-41; Ann Chisholm, "Nineteenth-Century Gymnastics for U.S. Women and Incorporations of Buoyancy: Contouring Femininity, Shaping Sex, and Regulating Middle-Class Consumption," Journal of Women's History 20, no. 3 (2008), 95-99. 
nalists such as Gustaf Abraham Silverstolpe (1772-1824) and Carl Ulric Broocman (1783-1812). ${ }^{13}$ This debate had strong international features. Jean-Jacques Rousseau's critique of civilisation was important, as were Johann Heinrich Pestalozzi's ideas on physical education, which was championed by Broocman. The influence of Johann Christoph Friedrich GutsMuths was marked by the translation of Gymnastik für die Jugend to Swedish in $1813 .{ }^{14}$

Concrete actions were also taken to promote physical education in Sweden. While the efforts to establish a professor's chair in physical education at Uppsala University in 1800 failed, gymnastics were mentioned for the first time in the school act of Swedish grammar schools in 1807. In 1813, the Royal Central Institute of Gymnastics (Kungliga gymnastiska centralinstitutet, GCI) was founded by Pehr Henrik Ling. ${ }^{15}$ The Royal Central Institute of Gymnastics became fundamental in the development of Swedish gymnastics, and its dissemination across the world. In 1814, a degree from the institute became prerequisite for teaching physical education in public schools. In 1820, gymnastics became an obligatory school subject in grammar schools, and through the school act of 1842 gymnastics became a subject in the thereby established national primary school system. ${ }^{16}$

Pehr Henrik Ling (1776-1839), usually credited as the creator of Swedish gymnastics, studied at Lund University and Uppsala University during the 1790s, earning a degree in theology. He subsequently worked as a civil servant in Stockholm, before moving to the Danish capital of Copenhagen in 1799, where he stayed until 1804. Apart from studies in philosophy and literature, Ling was introduced to the world of physical education. He attended a fencing school run by French immigrants, and the gymnasium of Franz Nachtegall (1777-1847), who was a pioneer of physical education in Denmark. In 1805, Ling moved to Lund, where he was appointed as fence master at Lund University and gave lessons in gymnastics. His reputation grew, partly due to a successful display in 1810, which made him known in the Swedish military. This may have contributed to Ling receiving a position as gymnastics teacher at the Royal War Academy at Karlberg, Stockholm, in 1813, and becoming the founding director of the Royal Central Institute of Gymnastics in the same year. ${ }^{17}$

13 Annerstedt (1989), 10-13; Ljunggren (1999), 63-69.

14 Annerstedt (1989), 23-24; Ljunggren (1999), 70-73.

15 Jens Ljunggren, "Nation-Building, Primitivism and Manliness: The Issue of Gymnastics in Sweden around 1800," Scandinavian Journal of History 21, no. 2 (1996), 111; Annerstedt (1989), 23-24.

16 Ljunggren (1999), 39. Regarding the role that the institute played in the international dissemination of Swedish gymnastics, see Meinander (1994), 36-38.

17 Ljunggren (1999) 36-37; P. C. McIntosh, “Therapeutic Exercise in Scandinavia," in Landmarks in the History of Physical Education, ed. J. G. Dixon, P. C. McIntosh, A. D. Munrow and R. F. Willetts (London: Routledge \& Kegan Paul, 2007), 86-91. Regarding Ling's position at the Royal War Academy, see Esbjörn Larsson, Från adlig uppfostran till borgerlig utbildning: Kungl. krigsakademien mellan åren 1792 och 1866 (Uppsala: Uppsala universitet, 2005), 224-26. 


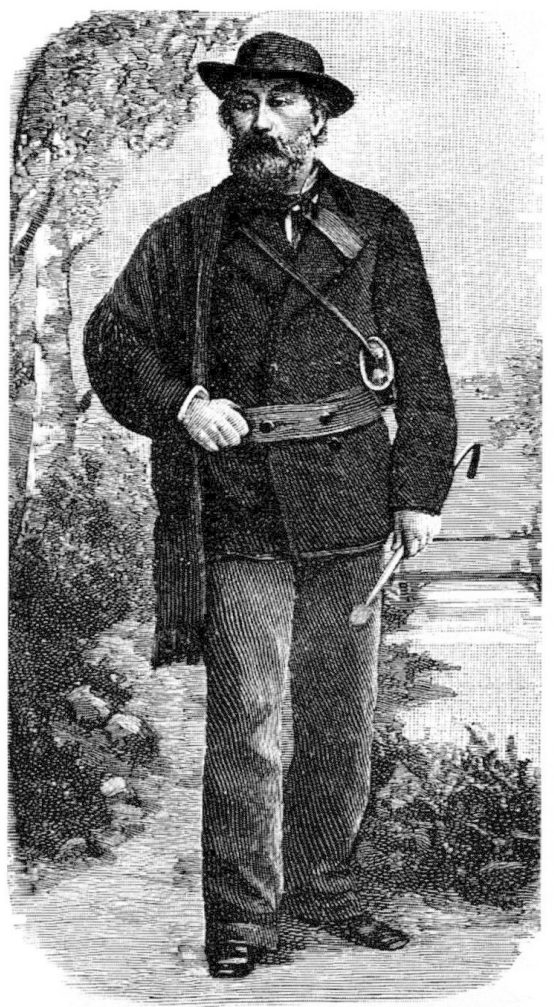

Figure 1. Anton Santesson (1825-1892).

Source: Svenskt biografiskt lexikon, s.v. "Santesson, släkt."

Following Ling's death in 1839, his leading role was overtaken by his followers, including Lars Branting (the director of the GCI during 1813-1862) and Pehr Henrik Ling's son Hjalmar Ling, who worked with educational gymnastics at the institute during the 1864-1882 period. This article focuses on the publications of one of these men, Anton Santesson (1825-1892), portrayed in Figure 1. Santesson's significance does not stem from a successful career. Instead, he frequently moved between grammar schools. After studies at Lund University, he worked as a teacher in physical education at the Royal Central Institute of Gymnastics in 1850, and thereafter in the grammar schools of Gothenburg (1852-), Karlstad (1854-), Strängnäs (1856-), and Karlstad (1861-), as well as the New Grammar School of Stockholm (1863-1876). ${ }^{18}$

Santesson was, however, a diligent writer, who rose to prominence in the world of gymnastics by authoring several handbooks, mainly in the 1860 s. Santesson's influence seems to have been particularly felt in Finland. ${ }^{19}$ At that time, handbooks on gymnastics were lacking. Pehr Henrik Ling did not publish any handbooks, and his son Hjalmar Ling started to publish slightly later than Santesson. In addition to being one of the main authors of gymnastics handbooks in Sweden, Santesson was also the main writer on the topic of girls' gymnastics alongside Hjalmar Ling. Santesson's handbook on gymnastics for young women and school girls was, for example,

18 Gunnar O. C. H. Santesson, Släkten Santesson från Långaryd (Karlshamn: Lagerblads tryckeri, 1982), 63-64.

19 The significance that Santesson's handbooks gained in Finland is noted in Sandblad (1985), 148. 
one of the two handbooks used in the department for women's gymnastics that was established at the Royal Central Institute of Gymnastics in $1864 .{ }^{20}$

Thus, Santesson's writings are an excellent starting point for gaining insight into the emerging girls' gymnastics in Sweden, and for elucidating how it was construed in terms of aims and practices. The analyses presented here pertain to the five handbooks on gymnastics that Santesson authored and articles he published in the journal Svenska gymnastik-föreningens tidskrift as its editor during 1865-1866. The handbooks vary in length, from 31 to 140 pages, and in content. Since the handbooks were intended to disseminate Santesson's visions of physical education, they included drawings of various exercises. Nevertheless, Santesson's writings expressed his wide-ranging interests that included not only the pedagogical practices of physical education, but also discussion on hygiene, physiology, the history of Sweden, and the social status of women. In my analysis, presented below, emphasis is placed on the three handbooks where girls' gymnastics were most widely discussed. These are Handbok i pädagogisk gymnastik för gymnasier och skolor (Handbook of Educational Gymnastics for Gymnasiums and Primary Schools), published in 1856; Folkskolans gymnastik (The Gymnastics of Primary Schools), published in 1859; and Gymnastik för unga qvinnor och skolflickor (Gymnastics for Young Women and Schoolgirls), published in 1866. In focusing on these sources, this article serves as a prelude to further studies into the educational debate on girls' and women's physical education in the educational journals, newspapers and handbooks of nineteenth century Sweden.

\section{Gymnastics and the educationalisation of the world}

Pehr Henrik Ling's system of physical education was based on a philosophy of nature inspired by GutsMuths and Rousseau, and a notion of the laws of human bodies. Adopting this perspective, he envisioned a system of gymnastics with four directions (military, educational, medical and aesthetic) which was supposed to enhance both body and mind in accordance with these laws and Ling's ethical and aesthetic ideals. As a result, he constructed a system of gymnastics based mainly upon freestanding exercises that also included apparatus exercises and training activities, such as walking, swimming and wrestling. ${ }^{21}$

The gymnastics envisioned in Santesson's handbooks did not depart much from that promoted by other Swedish authors on the subject, even though he probably put a greater emphasis on apparatus exercises and competition. ${ }^{22}$ This was not without purpose. Santesson described himself as one of Pehr Henrik Ling's oldest disciples, and desired to develop gymnastics in his spirit. Like Ling, Santesson defined gymnastics as exercises based on the laws of the human body intended to promote health and energy. ${ }^{23} \mathrm{He}$ also used Ling's distinction between educational, military, medi-

20 Santesson (1982), 63-64; Claes Annerstedt, Idrottslärarna och idrottsämnet: Utveckling, mål, kompetens: Ett didaktiskt perspektiv (Göteborg: Acta Universitatis Gothoburgensis, 1991), 127; Carli (2004), 115; Ester Svalling, "Den kvinnliga avdelningen vid Kungl. gymnastiska centralinstitutet 1864-1913," in Kungl. gymnastiska centralinstitutets historia 1813-1913 (Stockholm: P. A. Norstedt \& söner, 1913), 250; Ljunggren (1999), 155.

21 McIntosh (2007), 91-93; Ljunggren (1999), 104-06; Lundvall (2016), 154-55.

22 Cf. Sandblad (1985), 146.

23 See, e.g., Anton B. Santesson, Folkskolans gymnastik (Carlstad: s.n., 1859), 5; Anton B. Santesson, Folkskolans gymnastik och vapenföring (Carlstad: Agne Peterssons förlag, 1864), 1. 
cal and aesthetic gymnastics. In educational gymnastics - the topic that Santesson devoted most attention-he included both exercises that involved apparatuses and those that did not. The former included exercises involving ropes, pommel horses, bars and wall bars. The latter included exercises ranging from leg squats and pushups to marching exercises (see Figure 2). In addition, his handbooks presented running, wrestling, swimming and dancing exercises. ${ }^{24}$

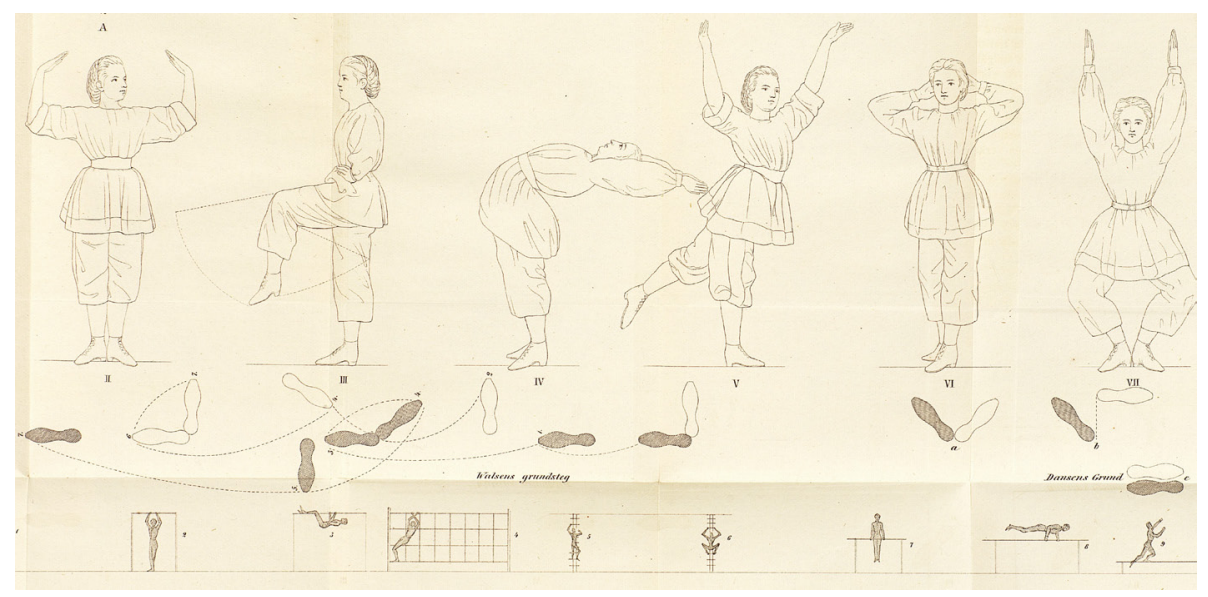

Figure 2. Examples of exercises included in girls' gymnastics. Source: Santesson (1866a).

As the other pioneers of Swedish gymnastics, Anton Santesson perceived gymnastics as not merely a collection of exercises that strengthen the body of individuals. ${ }^{25}$ For Santesson, gymnastics was also a political technique-a tool for creating national citizens with a certain set of characteristics, and thus also a tool for reforming Swedish society. Consequently, Santesson's discourse on gymnastics certainly educationalised the world, making it possible to enhance through gymnastics.

Promoting this process of educationalisation, Santesson argued that boys' as well as girls' gymnastics addressed several social problems. In general, gymnastics was described as a response to perceived adverse changes in contemporary society. Although Sweden remained a rural country in the early nineteenth century (in 1840, only 10 percent of the population lived in cities), Santesson portrayed gymnastics as a necessary response to a rapidly changing society. In this respect, one might describe Santesson's perspective as anticipatory in relation to future developments, which is a term that has been used to interpret the early development of the US school system. ${ }^{26}$ Using the words of Nikolas Rose and Peter Miller, Santesson's publi-

24 See, e.g., Anton B. Santesson, Handbok i pädagogisk gymnastik för gymnasier och skolor (Karlstad: s.n., 1856); Anton B. Santesson, Gymnastik för unga qvinnor och skolflickor (Stockholm: Bonnier, 1866).

25 See, e.g., Ljunggren (1996), 113-15.

26 John G. Richardson, "Historical Sequences and the Origins of Common Schooling in the American States," in Handbook of Theory and Research for the Sociology of Education, ed. John G. Richardson (New York: Greenwood Press, 1986), 48. Regarding the rural character of Sweden, see Carl-Johan Gadd, "On the Edge of a Crisis: Sweden in the 1840s," in When the Potato Failed: Causes and Effects of the 'Last' European Subsistence Crisis, 1845-1850, ed. Comarc Ó Gráda, Richard Paping and Eric Vanhaute (Turnhout: Brepols, 2007), 315. 
cations may certainly also be described as an intellectual machinery, that is a text that constructed an intelligible reality possible to not only understand, but also to change through gymnastics. ${ }^{27}$

In line with a widespread civilisation critique that, inspired by Jean-Jacques Rousseau, formulated the problem of contemporary society in terms of weakness, luxury, idleness and indulgence, Santesson argued that physical education addressed issues stemming from the macro-historical transition from a society of hunters to a society of civilisation. ${ }^{28}$ In the past, Santesson claimed, humans were forced to use their bodies to satisfy their physical needs. To support themselves by hunting and fishing, they had to cross forests, climb trees and swim in lakes. Their health and physical education was thereby guaranteed by providence. Although hard manual labour still dominated the largely rural nineteenth century Sweden, where a day's labour (dagsverke) meant 12 hours of work, Santesson argued that the progress of civilisation meant that reliance on one's bodily fitness was no longer necessary for survival. To compensate for this development, gymnastics were crucial to ensure physical health in modern societies. ${ }^{29}$

The discourse promoted by Santesson also transformed more specific societal changes into problems that could be solved by physical education. Unlike education in general, and school subjects such as English in US schools that addressed a wide variety of issues in contemporary society, Santesson claimed that gymnastics could solve the problems that education itself created. ${ }^{30}$ In the case of gymnastics, the process of educationalisation thus turned back towards itself. Although schooling remained rather limited in Sweden in mid-nineteenth century-in the 1850s, there were only about 7,000 pupils enlisted in Swedish grammar schools (läroverk), and in 1868 , estimates show that only 65 percent of school-aged children were enrolled in primary school for an average of two years, with an estimated attendance of 43 percent-education was described by Santesson as a problem that gymnastics could solve. $^{31}$

The problem of schooling was partly formulated in terms of specific issues, such as schoolchildren's sedentary lifestyle or the mental stress that schooling implied. Santesson attached special significance to the school desk. According to Santesson, school desks were detrimental to girls' posture. Since girls sat leaning forward during long school days, they were all too often unable to stand straight. School desks also created "crocked and inwardly bent shoulders", cripples and bookworms (bok-

27 Rose and Miller (1992), 182.

28 In the context of Sweden, this widespread critique of civilisation is discussed in Ljunggren (1999), 70-73.

29 Santesson (1856), 83. See also the references made to one of Santesson's speeches in T. J. Hartelius, "Gymnastikföreningens fest den 20 maj 1865," Svenska gymnastik-föreningens tidskrift 1, no. 1 (1865), 9. For references regarding the length of a day's work, see Johannes Westberg, Att bygga ett skolväsende: Folkskolans förutsättningar och framväxt 1840-1900 (Lund: Nordic Academic Press, 2014), 154.

30 Regarding the general educationalisation process, see Tröhler (2013), 2-4. Educationalisation in the context of the school subject English, see Brass (2016).

31 Jonas Ljungberg and Anders Nilsson, "Human Capital and Economic Growth: Sweden 1870-2000," Cliometrica 3, no. 1 (2009), 80; Wilhelm Sjöstrand, Pedagogikens historia III:2: Utvecklingen i Sverige under tiden 1805-1920 (Lund: Gleerup, 1965), 352. 
malar). ${ }^{32}$ The deficiencies of school desk have, in other contexts, been attributed inadequate school desk design, and were thus perceived as an issue of improving design. ${ }^{33}$ In Santesson's publications, however, such problems were instead a matter of physical education, and Santesson even claimed that bookworms, which he described as the cancer of grammar schools, would become rarer if gymnastics were to become more widespread across Sweden. ${ }^{34}$

Similarly, the issue of masturbation was educationalised in the sense that it was transformed from being merely a moral or medical issue into a problem that could be resolved by physical education. Against the background of a wider discourse on the perils of masturbation - which was perceived as simultaneously the cause and effect of moral degeneration-Santesson noticed how school work provided fertile ground for this dangerous vice that he claimed was conducted "on a large scale" at schools. In his view, when sitting still, bodily fluids gathered at the genitals and the pupils' minds were given opportunity to excel in what was described as the debaucheries of imagination. The mental pressure of schooling, the demands on maturity that schools placed on children, the reading of novels and the drinking of coffee, also caused this decease, according to Santesson. Since physical education promoted self-restraint, gymnastics accompanied with cleansing baths could thus be a part of the solution to this problem. ${ }^{35}$

Apart from specific issues, Santesson recognised a general problem with schooling, positing that schools distanced children from nature. He claimed that this relocation of children restricted their physical life and damaged their bodies. This was particularly strongly felt, Santesson claimed, in the competitive context of the nineteenth century, where pupils had to compete for grades, and thus not only studied late into the night during the week, but also on weekends and during holidays. ${ }^{36}$ Hence, the modern nineteenth-century school hurt not only the bodies of the youth, but also their souls. Through education, the freshness of youth was all too easily transformed to sadness, fragility and melancholy, and the extensive reading created hesitation and absentmindedness among the youth. In Santesson's view, physical education was a remedy for all these symptoms. ${ }^{37}$

This educationalisation of social, physiological, moral and psychological problems that rendered physical education as their potential solution was certainly part of what has been labelled a rationalisation and a medicalisation of the body. ${ }^{38}$ Santes-

32 Santesson (1856), 8, 77-78. The quote is from Santesson (1866d), 3.

33 See, e.g., Pedro L. Moreno Martinez, "History of School Desk Development in Terms of Hygiene and Pedagogy in Spain (1838-1936)," in Materialities of Schooling: Design - Technology - Objects Routines, ed. Martin Lawn and Ian Grosvenor (Oxford: Symposium Books, 2005), 71-95.

34 Santesson (1866d), 3.

35 Santesson (1856), 9; Anton B. Santesson, “Sedeförderfvet i skolorna," Svenska gymnastik-föreningens tidskrift 2, no. 1 (1866), 73-80. The Swedish discourse on masturbation is discussed in Jens Rydström, “'Sodomitical Sins Are Threefold:' Typologies of Bestiality, Masturbation, and Homosexuality in Sweden, 1880-1950," Journal of the History of Sexuality 9, no. 3 (2000), 244.

36 Santesson (1856), 82-83; Anton B. Santesson, “Om elementarläroverkens gymnastikmönstring samt skolgymnastikens bedömande af svenska läkaresällskapet," Svenska gymnastik-föreningens tidskrift 1, no. 1 (1865), 113.

37 Santesson (1856), 64; Santesson (1866a), 12.

38 Regarding these concepts of medicalisation and rationalisation, see e.g., Bryan S. Turner, Regulating Bodies: Essays in Medical Sociology (London: Routledge, 1992), 19-22. 
son based his arguments on a wider debate pertaining to the health of schoolchildren in Sweden, and in the West. During the latter half of the nineteenth century, educationalists, teachers and psychiatrists became increasingly concerned with schoolchildren's mental overexertion, fatigue, sluggishness and growing immorality. ${ }^{39}$ In France, many of these symptoms of intellectual exhaustion were subsumed under the diagnostic term la céphalagie scolarie (scholar's brain), which was used to describe the educational system's "victims scolaires." ${ }^{40}$ In the case of Swedish gymnastics, this rationalisation of the body did not imply its secularisation. As evident from above, Santesson's discourse was firmly rooted in Christian belief in the close linkage between body and soul. Some of Santesson's arguments in support of gymnastics also employed the narrative structure of a divine punishment: when individuals in the modern society turned their back on nature, they were punished with bad mental and physical health. Hence, only if they acknowledged their sinful ways and turned to gymnastics, they could be salvaged from the detrimental effects of modern society. ${ }^{41}$

In addition to saving individuals from the perils of modern society, Santesson claimed that gymnastics benefited the Swedish nation. By hampering the fostering of bookworms, and providing boys and young men with the required physical exercise, gymnastics would strengthen the Swedish nation. Specifically, Santesson addressed the issue of the Swedish army. If gymnastics and weapons training (vapenövningar) were implemented across all Swedish schools, gymnastics would be become an integral part of the Swedish military. ${ }^{42}$ Such an arrangement, which would provide schoolchildren with the appropriate physical and military training, would enable the creation of a large army at a low cost. In that respect, Santesson argued that gymnastics would contribute to the development of the militant temperament of the Swedish nation that was instrumental to so many past victories over Denmark, Russia, Poland, Turkey and Germany. To quote Santesson, gymnastics would prevent the Swedes from forgetting their "Viking Ancestry." ${ }^{43}$ In this respect, Santesson based his arguments for gymnastics on the notions of the heroic Vikings, promoted by the Swedish Gothicism movement. ${ }^{44}$

Gymnastics could also serve the Swedish nation in a more general sense that Santesson described in terms of the force ( $k r a f t)$ of the Swedish nation. According to Santesson, the superior force that the Swedish nation had developed was widely acknowledged. He quoted a German statistician (Fränzt) who claimed that one

39 Bode Janzon, Manschettyrken, idrott och hälsa: Studier kring idrottsrörelsen i Sverige särskilt Göteborg, intill 1900 (Göteborg: Göteborgs universitet, 1978), 21-23; Christopher Bischof, "A 'Rich Crop of Nervousness': Childhood, Expertise, and the State in the mid-1880s British Over-Pressure Controversy," The English Historical Review 131, no. 553 (2016).

40 Anson Rabinbach, The Human Motor: Energy, Fatigue, and the Origins of Modernity (Los Angeles: University of California Press, 1992), 148.

41 Turner (1992), 22; David Larsson Heidenblad, Vårt eget fel: Moralisk kausalitet som tankefigur från 00-talets klimatlarm till förmoderna syndastraffsföreställningar (Höör: Agering, 2012), 229-31.

42 Weapons training, including fencing, rifle drills and shooting practice, was introduced in Swedish schools in 1863, see Esbjörn Larsson, "Barn från Mars - Skolungdomens vapenövningar," Militärhistorisk Tidskrift 2013 (2014), 149-53.

43 Santesson (1856), 85.

44 Regarding these notions of the heroic pasts of the Vikings, see Ljunggren (1999), 83-87. 
must marvel at the impact of the force of two million Swedes on Europe during the last 200 years. Santesson supported his argument by pointing at famous individuals: Linneaus, who Santesson described as the king of the kingdom of flowers, Jöns Jacob Berzelius, the discoverer of chemical elements, and Pehr Henrik Ling, the inventor of gymnastics. It was this strength of the Swedish nation that, according to Santesson, gymnastics would support. ${ }^{45}$

\section{Strengthening women's bodies and minds}

In addition to presenting gymnastics as a response to a wide range of problems, Santesson specifically focused on the problem of the health of Swedish women, which he-in accordance with the general mechanism of educationalisation-largely interpreted as an educational problem that could be solved using physical education.

Santesson's problematisation of women's health drew upon a long-standing gender dichotomy between strong male and weak female bodies, which had been recurrent throughout history, and persisted in the contemporary nineteenth-century debates. In support of this stance, individual examples of the fragility of girls' and women's bodies were provided, along with anecdotal evidence and investigations. For example, it was noted that girls in private schools generally complained of headache, and witnesses testified that fatigue and drowsiness reached epidemic proportions at the end of each academic year. ${ }^{46}$

Santesson's problematisation of women's health also stemmed from his critique of the modern society. According to Santesson, women's health problems were, in part, caused by "false opinions" that meant that girls were not allowed to run and play to the same extent as boys did. He also discussed detrimental fashion trends, while criticising the widespread use of tobacco, coffee and punsch (Swedish liquor based on arrack) in modern Sweden, which "corroded the marrow" of both men and women. Santesson lamented that, while westerners found it strange that feathers were placed through women's noses in foreign countries, Western women nevertheless "mutilate and ridicule" themselves with ear piercings and corsets. Apart from restricting women's movements, Santesson argued that the latter "modern shackles" inflicted not only pain and nasty wounds but also damaged women's respiratory organs. ${ }^{47}$

Santesson claimed that it was not surprising that women, under such circumstances, suffered from health issues. He supported this assertion with statistics, which had grown in significance during the first half of the nineteenth century: the period 1830-1850 has been described as the "era of enthusiasm for statistical data collection" while that spanning 1820-1840 is referred to as an "avalanche of printed numbers." ${ }^{48}$ Although scholars have noted that the statistical data was not particularly reliable, the manifest precision of statistics made it appear as a rational method

45 Santesson (1856), 85-86.

46 Janzon (1978), 29. Regarding the recurrent concern about women's bodies, and the belief of women as the weaker sex, see Vertinsky (1994), 1-8. Late nineteenth century debate in Sweden on the health of school girls is analysed in Anna-Karin Frih, Flickan i medicinen: Ungdom, kön och sjuklighet 1870-1930 (Örebro: Örebro universitet, 2007), ch. 5-7.

47 Santesson (1856), 77-79; Santesson (1864), xiv-xv. The quotes are from Santesson (1856), 78.

48 Ian Hacking, "Biopower and the Avalanche of Printed Numbers," in Biopower: Foucault and Beyond, ed. Vernon Cisney and Nicolae Morar (Chicago: University of Chicago Press, 2016), 67. 
to map and manage an elusive reality. ${ }^{49}$ Santesson used this trust in, and enthusiasm for, statistics when arguing for girls' gymnastics. When discussing the need for girls' gymnastics, he quoted the statistician Carl af Forsell (1783-1848) who claimed that every eight married woman in Sweden was childless, every fiftieth woman died during childbirth, and every thirty-fifth woman gave birth to a stillborn child. ${ }^{50}$

When describing the health problem that girls' gymnastics could solve, such statistical data was complemented with individual examples of bad health, and observations of the general physical and mental state of girls and women. Santesson claimed that mothers were no longer able to breastfeed their infants, and described in great detail general trends that featured increasing number of anaemic girls, girls with crooked backs, and girls who-with a bored and sickly look-hauled themselves forward with their feet bent inwards and their heads bowed. ${ }^{11}$ True to his character (Santesson was renowned for his temper and frankness), Santesson illustrated the state of women's health by rudely discussing the case of a county governor's daughter in southern Sweden. In part due to the lack of physical exercise, she had the appearance of a piece of meat or a changeling (bortbyting) — that is, a troll child that trolls secretly had substituted for a human child. ${ }^{52}$

In this context, these various health problems were educationalised in the sense that they were presented as if they could be remedied by the implementation of girls' gymnastics. Reflecting on feminine beauty ideals, Santesson claimed that gymnastics did not only make women healthier, but also more beautiful, and more appealing in posture and movement. When discussing the county governor's daughter mentioned above, Santesson noted that such lumpish girls could be "refined" by gymnastics, becoming creatures similar to other human beings. ${ }^{53}$ Santesson also supported his arguments with a number of individual examples that illustrated the effectiveness of girls' gymnastics. In the city of Malmö, he claimed, anaemic girls had become stronger and healthier after practicing gymnastics every second day for a couple of months. In Strängnäs and Karlstad, girls' gymnastics had initially been perceived as something remarkable and impossible. Nevertheless, it had been very appreciated by parents, who noticed the grace that it gave their daughters. In Prussian Poland (probably the city of Posen that Santesson visited in 1854), nervous young women

49 Henrik Höjer, Svenska Siffror: Nationell Integration och Identifikation genom Statistik 1800-1870 (Hedemora: Gidlund, 2001), 127-28.

50 Santesson (1856), 79.

51 Anton B. Santesson, "Gymnastik för unga qvinnor och skolflickor," Svenska gymnastik-föreningens tidskrift 2, no. 1 (1866): 81-82.

52 Santesson (1866a), 6. Although Santesson probably did not believe in changelings, the belief that trolls actually stole unbaptised children was found among the Swedish rural population in the nineteenth century. Stina Bohman, Omsorg om livet: Spädbarnsdödlighetens förändring $i$ Ådalen under 1800-talet (Uppsala: Uppsala universitet, 2010), 58-60.

53 Santesson (1856), 80; Santesson (1866a), 6-11. For a theoretical description of feminine beauty ideals, see, e.g., Lori Baker-Sperry and Liz Grauerholz, "The Pervasiveness and Persistence of the Feminine Beauty Ideal in Children's Fairy Tales," Gender \& Society 17, no. 5 (2003): 711-13. The notions of feminine beauty in gymnastics, and its varying functions in that context, deserves further studies. It may, for example, be noted that the Danish gymnast promoter Niels Bukh (1880-1950), did not select female gymnast to his elite teams merely based on gymnastic skills, but preferred pretty women with blonde hair. Hans Bonde, Gymnastics and Politics: Niels Bukh and Male Aesthetics (Copenhagen: Museum Tusculanum, 2006), 41. Bukh's visions of gymnastics is examined in Hans Bonde's contribution to this special issue. 
not only regained their health, but also developed their interest in gymnastics. In Stockholm, female teachers in all primary schools taught gymnastics. The fact that they continued to do so, even though gymnastics was not a compulsory subject, bore testament to its benevolent effects. ${ }^{54}$

Gymnastics also strengthened the mind of girls and women. Instead of using statistics or general impressions, Santesson supported this claim with quotes from esteemed individuals. He quoted Pehr Henrik Ling, who claimed that, in educational gymnastics, the mind is affected by the body. Santesson also drew on Plato, who according to Santesson claimed that mere mental exercises made individuals weak, and those who only exercise their body become hard-hearted and rebellious. To obtain a male soul in a forceful body, a combination of mental and physical exercises was thus necessary. Santesson also noted that Martin Luther saw this connection between the body and the mind. According to Luther, gymnastics gave students resilience against fornication, drunkenness and gambling. ${ }^{55}$

When presenting the effects of gymnastics on the female mind, Santesson stressed a series of benefits. According to Santesson, gymnastics enabled women to better deal with their "female troubles." Gymnastics made girls more lively, vigorous and relaxed, and prevented them from becoming depressed because of the worries that the pressure of schooling created. Gymnastics also fostered positive character traits, such as dignity, consistency, self-criticism, determination, self-control and courage. ${ }^{56}$ Exercises involving the head and neck were, for example, deemed important from a moral standpoint, since "it is a fact" that sorrow and troubles do not affect a head held high. Jumping exercises were similarly important, since they strengthened qualities such as calculation and determination. ${ }^{57}$ This close connection between mind and body that these claims presupposed also underlies Santesson's argument for introducing schoolchildren, and girls in particular, to swimming. Due to the intimate union of body and soul, Santesson claimed that the washing of a body cleansed the soul from impure thoughts. ${ }^{58}$ In the context where the physical and mental dangers of schoolchildren's increasingly frequent habit of masturbation were discussed, such an effect of physical education was, naturally, of great significance. ${ }^{59}$

These mental benefits of gymnastics were deemed particularly important, since the position of women in the society was changing. Santesson acknowledged that women's status had been weak, and that men seldom had presented women with serious tasks. Instead, Swedish women first received inheritance rights in the mid-nineteenth century, having previously had a position described by Santesson as somewhere between children and lunatics. ${ }^{60}$ But, in 1866, Santesson acknowledged that women in recent years had been given opportunities to become more independent from men. This was true, as apart from being presented with the same in-

54 Anton B. Santesson, "Gymnastik för unga qvinnor och skolflickor," Svenska gymnastik-föreningens tidskrift 1, no. 1 (1865), 128-30.

55 Santesson (1856), 84-85; Santesson (1866a), 94.

56 Santesson (1866a), 4, 11-12, 38, 41; Santesson (1865a), 130.

57 Santesson (1866a), 45-46, 59. The quote is from pages 45-46.

58 Santesson (1866a), 87-88.

59 The problem of masturbation is also discussed in Santesson (1856), 9; and Santesson (1866c), 7281.

60 Santesson (1865a), 127; Santesson (1856), 79. 
heritance rights as men in 1845, unmarried women became legally competent at the age of 25 in 1858. In 1859, women were allowed to enter the profession of primary school teachers, and were given some voting rights at municipal elections in $1862 .{ }^{61}$ Under such circumstances, Santesson argued that girls' gymnastics had a crucial role to play. Basing his arguments upon the notion of gender differences in which women were perceived as the lesser sex, Santesson claimed that women's weaknessesincluding their tendency to be overwhelmed by their emotions-may have been tolerated in the past. Such weakness could, however, not be accepted in the new era that was dawning. The courage and health that gymnastics provided women would consequently be crucial for the future of women. ${ }^{62}$

\section{Women and the Swedish nation}

This educationalisation of women's bodies and minds was, however, also extended to the Swedish society, as Santesson argued that girls' gymnastics would strengthen the Swedish nation and support its development towards physical health, national identity and independence. ${ }^{63}$ This is not surprising. The nineteenth century was an intense period of nation formation in Sweden and elsewhere. The Swedish national identity construction has been described as a complex process, in which voluntary associations as well as the bourgeoisie and the Swedish state participated in various ways. ${ }^{64}$ The educational system certainly played an important part in this endeavour, and the history of gymnastics and nationalism was closely intertwined; the body-building process was, in the words of Rebekka Horlacher, partly parallel to the nation-building process. ${ }^{65}$ For Pehr Henrik Ling, gymnastics was vital to the nationalist project, since the strength of the Swedish nation depended on the manliness and physical strength of its population. ${ }^{66}$

Santesson believed, as evident from above, that the purpose of gymnastics was to foster national citizens that could support a strong Swedish nation. Gymnastics was in this respect certainly a part of the national identity construction process that can be described in terms of internal colonisation or civilising mission. ${ }^{67}$ To paraphrase Eugene Weber, Swedish gymnastics was about making weaklings into Swedish Vikings. ${ }^{68}$ But unlike Pehr Henrik Ling, Santesson did not see men and their manliness

61 For an overview of these reforms in the history of women's rights, see Jan Melin et al., Sveriges historia: Koncentrerad uppslagsbok: Fakta, årtal, kartor, tabeller (Stockholm: Prisma, 2006), 479.

62 Santesson (1866a), preface, 15. Regarding gender, power and inequality, see, e.g., Scott (1986), $1072-73$.

63 Santesson (1866a), 12.

64 Anne Berg, Kampen om befolkningen: Den svenska nationsformeringens utveckling och sociopolitiska förutsättningar ca 1780-1860 (Uppsala: Uppsala universitet, 2011), 19-21. See also Patrik Hall, The Social Construction of Nationalism: Sweden as an Example (Lund: Lund University Press, 1998).

65 See Rebekka Horlacher's contribution to this special issue. Regarding the relationship between schooling and the creation of national citizens, see, e.g., the classic formulations of Hobsbawm in Eric Hobsbawm, Nations and Nationalism Since 1780: Programme, Myth, Reality (Cambridge: Cambridge University Press, 1992), ch. 3.

66 Ljunggren (1996), 117.

67 Cf. Eugen Weber, Peasants into Frenchmen: The Modernization of Rural France, 1870-1914 (Stanford: Stanford University Press, 1976), 485-90.

68 The qualities of this Swedish Viking, and how he was understood in relationship to a bourgeois manhood ideal is discussed in Ljunggren (1999), 83-88. 
as the key to strengthening the Swedish nation. Instead, he aligned his arguments with contemporaries who saw women as fundamental to the nationalist project, and argued that the future of the Swedish nation lay in the hands of women, rather than men. ${ }^{69}$ Santesson purported that it was short-sighted to only introduce gymnastics at schools for boys, and mistakenly believe that the foundation of the strength, courage and high-mindedness of the Swedish nation had been laid. Admittedly, boys' gymnastics would contribute to this development, but Santesson believed that girls' gymnastics formed the basis of the Swedish population's rise towards health, national identity and independence. ${ }^{70}$

Santesson's line of argument started with the family. He claimed that, if one is searching for the origins to a nation's customs and habits, one will eventually end up in the family, the home. Therein lay the secret to the qualities of a people, according to Santesson, whether these were faulty or commendable, virtuous or vicious. This conclusion was in line with the contemporary social and political interest in the family_one might even speak of a contemporary familialisation of society — which put families at the centre of philanthropic and educational initiatives, and later social work and psychiatry. By using family life as a safeguard against the dangers of the life at pubs and in streets, it was believed that several social ends could be met, including the curbing of alcoholism, promiscuity and crime. ${ }^{71}$

Santesson's analysis did, however, not end there. The family was important to society, but Santesson argued that, when one looks closely enough, the matron and the woman emerges as the thinnest root to nation's common qualities. On a general level, Santesson explained this fact by claiming that mothers' hearts beat in the same pace across the Swedish nation, leaving the same impression on everyone nurtured at these mothers' bosoms. To raise a daughter, is thus to raise society. ${ }^{72}$ Santesson also acknowledged more specific mechanisms through which girls' physical education affected the Swedish nation. Strong and beautiful women would bestow the nation with strong and beautiful sons, while women's increased knowledge of physical education would improve the rearing of boys. Through gymnastics, the many mistakes mothers make regarding the diet and clothing of their children would be removed, and mothers' scepticism towards children's physical education would vanish. ${ }^{73}$ Using such arguments, Santesson successfully combined the value of manliness with the importance of girls' gymnastics: manliness remained fundamental to the strength of a nation, but the physical education of girls was fundamental to the manliness of men.

In the intellectual machinery of this political rationality, Santesson did not rely solely on statistics, general impressions and hearsay, but also used simple stories to describe the intimate relationship between the physical education of girls and the development of the Swedish nation. Santesson recounted, for example, the story of

69 This link between women and the Swedish nation was, for example, highlighted in a state committee in 1869, see Ljunggren (1999), 159, and endnote no 143 on page 286.

70 Santesson (1866a), 12, 16.

71 Jacques Donzelot, The Policing of Families (London: Johns Hopkins University Press, 1997), ch. 1-4; Nikolas Rose, Governing the Soul: The Shaping of the Private Self (London: Free Association Books, 1999), 128-30.

72 Santesson (1866a), 12-13.

73 Santesson (1856), 80-81, 89. 
a woman who was six months pregnant with a baby girl. One beautiful spring day, about thirty years ago, the woman was walking from her house to a nearby garden. Her 7-year-old son said that he wanted to show her something that he carried in his hands, and when she leaned in to have a look, a beautiful butterfly suddenly emerged from his hands. Surprised, the women slapped her hip with the palm of her hand. When her daughter was born three months later, the daughter had a wound on her hip that refused to heal. But when it finally did, the wound transformed into a perfect image of a butterfly. Although Santesson admitted that this was an unusual case, he argued that it proved the intimate bond between mothers and their daughters. Thus, he claimed that the girls' gymnastics would have a strong impact not only on girls but these girls' future children. ${ }^{74}$ Although such narratives might seem imaginative, they were certainly one of the many cogs of the intellectual machinery that Santesson used in his efforts to justify girls' gymnastics.

Establishing this link between girls, women and the future of the nation, Santesson based his arguments on contemporary discourses in which women were assigned vital responsibilities in the nation-building process. Although the nation was imagined as a masculine community that men served in the public sphere, these discourses stressed that, by raising future citizens and imparting the national language and culture on them, women played an equally vital role. In essence, this responsibility was as important as those of men, but it was nevertheless often portrayed as dependent on the actions of men. Only when being protected by men, women could perform their duties. ${ }^{75}$ In the case of gymnastics, this gender disparity, as evident from above, was not used mainly to maintain women's subordinate status. Instead, the role of women in the nation-building process served as an argument to extend the rights of women to also include the possibility to participate in gymnastics.

\section{In conclusion}

Employing the concept of educationalisation, I have in this article shown how the purpose of girls' gymnastics was tied to various social, cultural and moral problems. In this respect, gymnastics was not only aimed at promoting the physical wellbeing of individuals, but also served to elevate the status of their minds and the strength of the Swedish nation. In this respect, the discourse on gymnastics is a particularly interesting case of educationalisation, since it is one of the instances when the consequences of education was interpreted as a problem that education, and more specifically physical education, could solve. The detrimental effect of schooling on children's bodies and minds was, according to Santesson, one of the problems that physical education could solve.

As evident from this article, several difficulties had to be overcome if girls' gymnastics was to be established in Sweden. It had to manage the already established link between gymnastics, manliness and the Swedish nation, and present a vision of the impact of gymnastics not only on girls but also on the Swedish society. There was

74 Santesson (1866a), 13-15.

75 Ida Blom, "Gender and Nation in International Comparison," in Gendered Nations: Nationalisms and Gender Order in the Long Nineteenth Century, ed. Ida Blom, Karen Hagemann and Catherine Hall (Oxford: Berg, 2000), 16-17; Silke Wenk, "Gendered Representations of the Nation's Past and Future," in Gendered Nations: Nationalisms and Gender Order in the Long Nineteenth Century, ed. Ida Blom, Karen Hagemann and Catherine Hall (Oxford: Berg, 2000), 64-65. 
also the issue of engaging in civilisation critique in a country where 90 percent of the population still lived in rural settings in the 1840s, where only a few were admitted to grammar schools and where the enrolment level in primary schools was still at 65 percent in 1868 .

In order to present girls' gymnastics in a manner that addressed these challenges, Santesson described it as a response to the precarious state of women's health that could strengthen both the Swedish nation and the bodies and minds of individual women. In investigating this vision, this article has provided the existing body of research on these topics with an additional example of how notions of motherhood and women's health was used to promote the cause of gymnastics. In addition to presenting the first in-depth analysis of Anton Santesson's educational visions, the main contribution of this article to the research on girls' and women's gymnastics stems from the emphasis on the complexity of the discourse of girls' gymnastics. In this case, Santesson promoted girls' gymnastics using a complicated set of partly inconsistent notions and ideas. The idea of girls' gymnastics was conceptualised and justified using the ideology of the nation, (almost) eternal concerns for women's bodies and a discourse that gave the family a vital role in society. In his vision of gymnastics, Santesson also included critique of civilisation, statistical data on women's health and gendered perceptions of feminine beauty, along with the beliefs about masturbation, medical and quasi-medical conceptions of the body, materialist conception of energy, a nationalistic ideology of the Swedish nation and gothicistic conceptions of Vikings. To support his arguments, he also used various kinds of evidence, including statistical data, individual cases, hearsay, general impressions and quotes from Plato, Martin Luther and Pehr Henrik Ling. By relying on this evidence, Santesson could create an image of mass education and civilisation which required the implementation of physical education at schools.

The inconsistencies and the lack of systematically chosen notions and evidence sources should, however, not be seen as a mistake, or as a result of an irrational thought process. Instead, the wide range of notions and sources of evidence may be perceived as essential components of the intellectual machinery developed by Santesson in order to conceive the aims and practices of gymnastics. Despite this eclectic character, Santesson's political rationality had concrete consequences. Apart from enabling Santesson to think about girls' gymnastics, and legitimating its establishment in Sweden, this rationality was also part of what has been termed the educationalisation of the world - that is, construing social problems as educational problems.

The complexity of Santesson's vision is also of wider interest. It is certainly an example of how political discourses generally lack the relatively systematic and clearly demarcated character of scientific discourses. ${ }^{76}$ In the political discourse under study, statistics was combined with the individual example of a county governor's daughter, moral-aesthetic notions of the significance of good posture, medical notions of mental fatigue, and quasi-religious notions of water being able to cleanse the soul from impure thoughts. Scientific analyses of body movements were combined with descriptions of a near magical relationship between mother and daughter, and descriptions of societal development that shares the structure of narratives of divine

76 Regarding this characteristic of political discourses, see Rose and Miller (1992), 178. 
punishment. Contrary to what is sometimes claimed, Santesson's political vision of girls' gymnastics demonstrates that the medicalisation of the body that does not necessarily imply its secularisation. ${ }^{77}$ Instead, such political discourses had the ability to combine the most diverse of elements.

By emphasising the complexity of Santesson's discourse, this article also highlights the historical particularity of such political discourses. While Santesson's vision of girls' gymnastics can certainly be described on a general level as a rationalisation, nationalisation and educationalisation of the body, this analysis shows that such processes are always specific. Sceptical about grand narratives, I would argue that this case of girls' gymnastics illustrates that there are no general cases of educationalisation, rationalisation, or nationalisation. Instead, such processes only exist in specific historical non-reducible forms.

$\overline{77 \text { Cf. Turner (1992), }} 22$. 


\section{References}

Annerstedt, Claes. Idrottslärarna och idrottsämnet: Utveckling, mål, kompetens: Ett didaktiskt perspektiv. Göteborg: Acta Universitatis Gothoburgensis, 1991.

Annerstedt, Claes. Skolgymnastikens utveckling i Sverige. Göteborg: Göteborgs universitet, 1989.

Baker-Sperry, Lori and Liz Grauerholz. "The Pervasiveness and Persistence of the Feminine Beauty Ideal in Children's Fairy Tales." Gender \& Society 17, no. 5 (2003), 711-26.

Barker-Ruchti, Natalie. “'Stride Jump - Begin!': Swedish Gymnastics in Victorian England." Sporting Traditions 22, no. 2 (2006), 13-29.

Bazoge, N., J. Saint-Martin, and M. Attali. "Promoting the Swedish Method of Physical Education Throughout France for the Benefit of Public Health (1868-1954)." Scandinavian Journal of Medicine \& Science in Sports 23, no. 2 (2013), 232-43.

Berg, Anne. Kampen om befolkningen: Den svenska nationsformeringens utveckling och sociopolitiska förutsättningar ca 1780-1860. Uppsala: Uppsala universitet, 2011.

Bischof, Christopher. "A 'Rich Crop of Nervousness': Childhood, Expertise, and the State in the mid-1880s British Over-Pressure Controversy." The English Historical Review 131, no. 553 (2016), 1415-44.

Blom, Ida. "Gender and Nation in International Comparison." In Gendered Nations: Nationalisms and Gender Order in the Long Nineteenth Century, edited by Ida Blom, Karen Hagemann and Catherine Hall, 3-26. Oxford: Berg, 2000.

Blom, Ida, Karen Hagemann, and Catherine Hall, eds. Gendered Nations: Nationalisms and Gender Order in the Long Nineteenth Century. Oxford: Berg, 2000.

Bloomfield, Anne. "Martina Bergman-Osterberg (1849-1915): Creating a Professional Role for Women in Physical Training." History of Education 34, no. 5 (2005), 517-34.

Bohman, Stina. Omsorg om livet: Spädbarnsdödlighetens förändring $i$ Ådalen under 1800-talet. Uppsala: Uppsala universitet, 2010.

Bonde, Hans. Gymnastics and Politics: Niels Bukh and Male Aesthetics. Copenhagen: Museum Tusculanum, 2006.

Brass, Jory. "English Teaching and the Educationalisation of Social Problems in the United States, 1894-1918." Paedagogica Historica 52, no. 3 (2016), 221-35.

Carli, Barbro. The Making and Breaking of a Female Culture: The History of Swedish physical Education 'in a Different Voice'. Göteborg: Göteborgs universitet, 2004.

Chisholm, Ann. "Gymnastics and the Reconstitution of Republican Motherhood among True Women of Civic Virtue, 1830-1870." The International Journal of the History of Sport 23, no. 8 (2006), 1275-313.

Chisholm, Ann. "Incarnations and Practices of Feminine Rectitude: Nineteenth-Century Gymnastics for U.S. Women." Journal of Social History 38, no. 3 (2005), 737-63.

Chisholm, Ann. "Nineteenth-Century Gymnastics for U.S. Women and Incorporations of Buoyancy: Contouring Femininity, Shaping Sex, and Regulating Middle-Class Consumption." Journal of Women's History 20, no. 3 (2008), 84-112.

Dean, Mitchell. Governmentality: Power and Rule in Modern Society. London: Sage, 2010. 
Donzelot, Jacques. The Policing of Families. London: Johns Hopkins University Press, 1997.

Fletcher, Sheila. Women First: The Female Tradition in English Physical Education, 1880-1980. London: Athlone, 1984.

Frih, Anna-Karin. Flickan i medicinen: Ungdom, kön och sjuklighet 1870-1930. Örebro: Örebro universitet, 2007.

Gadd, Carl-Johan. "On the Edge of a Crisis: Sweden in the 1840s." In When the Potato Failed: Causes and Effects of the 'Last' European Subsistence Crisis, 1845-1850, edited by Comarc Ó Gráda, Richard Paping and Eric Vanhaute, 313-42. Turnhout: Brepols, 2007.

Hacking, Ian. "Biopower and the Avalanche of Printed Numbers." In Biopower: Foucault and Beyond, edited by Vernon Cisney and Nicolae Morar, 65-81. Chicago: The University of Chicago Press, 2016.

Hall, Patrik. The Social Construction of Nationalism: Sweden as an Example. Lund: Lund University Press, 1998.

Hartelius, T. J. "Gymnastikföreningens fest den 20 maj 1865." Svenska gymnastik-föreningens tidskrift 1, no. 1 (1865), 9-17.

Hobsbawm, Eric. Nations and Nationalism Since 1780: Programme, Myth, Reality. Cambridge: Cambridge University Press, 1992.

Höjer, Henrik. Svenska Siffror: Nationell Integration och Identifikation genom statistik 1800-1870. Hedemora: Gidlund, 2001.

Janzon, Bode. Manschettyrken, idrott och hälsa: Studier kring idrottsrörelsen i Sverige särskilt Göteborg, intill 1900. Göteborg: Göteborgs universitet, 1978.

Larsson, Esbjörn. Från adlig uppfostran till borgerlig utbildning: Kungl. krigsakademien mellan åren 1792 och 1866. Uppsala: Uppsala universitet, 2005.

Larsson, Esbjörn. "Barn från Mars - Skolungdomens vapenövningar." Militärhistorisk Tidskrift 2013 (2014), 147-64.

Larsson Heidenblad, David. Vårt eget fel: Moralisk kausalitet som tankefigur från oo-talets klimatlarm till förmoderna syndastraffsföreställningar. Höör: Agering, 2012.

Lindroth, Jan. Idrottens väg till folkrörelse: Studier i svensk idrottsrörelse till 1915. Uppsala: Uppsala universitet, 1974.

Ljungberg, Jonas and Anders Nilsson. "Human Capital and Economic Growth: Sweden 1870-2000." Cliometrica 3, no. 1 (2009), 71-95.

Ljunggren, Jens. Kroppens bildning: Linggymnastikens manlighetsprojekt 1790-1914. Eslöv: Symposion, 1999.

Ljunggren, Jens. "Nation-Building, Primitivism and Manliness: The Issue of Gymnastics in Sweden around 1800." Scandinavian Journal of History 21, no. 2 (1996), $101-20$.

Lundquist Wanneberg, Pia. Kroppens medborgarfostran: Kropp, klass och genus $i$ skolans fysiska fostran 1919-1962. Stockholm: Stockholms universitet, 2004.

Lundvall, Suzanne. "Gender Dynamics in the Making and Breaking of a Female PETE Culture in Sweden." In The Female Tradition in Physical Education: 'Women First' Reconsidered, edited by David Kirk and Patricia Vertinsky, 153-69. London: Routledge, 2016. 
McIntosh, P. C. “Therapeutic Exercise in Scandinavia." In Landmarks in the History of Physical Education, edited by J. G. Dixon, P. C. McIntosh, A. D. Munrow and R. F. Willetts, 81-106. London: Routledge \& Kegan Paul, 2007.

Meinander, Henrik. Towards a Bourgeois Manhood: Boys' Physical Education in Nordic Secondary Schools 1880-1940. Helsinki: Societas scientiarum Fennica, 1994.

Melin, Jan, Alf W. Johansson, and Susanna Hedenborg. Sveriges historia: Koncentrerad uppslagsbok: Fakta, årtal, kartor, tabeller. Stockholm: Prisma, 2006.

Moreno Martinez, Pedro L. "History of School Desk Development in Terms of Hygiene and Pedagogy in Spain (1838-1936)." In Materialities of Schooling: Design - Technology - Objects - Routines, edited by Martin Lawn and Ian Grosvenor, 71-95. Oxford: Symposium Books, 2005.

Pfister, Gertrud. "Women in Sport - Gender Relations and Future Perspectives." Sport in Society 13, no. 2 (2010), 234-48.

Rabinbach, Anson. The Human Motor: Energy, Fatigue, and the Origins of Modernity. Los Angeles: University of California Press, 1992.

Richardson, John G. "Historical Sequences and the Origins of Common Schooling in the American States." In Handbook of Theory and Research for the Sociology of Education, edited by John G. Richardson, 35-63. New York: Greenwood Press, 1986.

Rose, Nikolas. Governing the Soul: The Shaping of the Private Self. London: Free Association Books, 1999.

Rose, Nikolas and Peter Miller. "Political Power Beyond the State: Problematics of Government." British Journal of Sociology 43, no. 2 (1992), 173-205.

Rydström, Jens. "'Sodomitical Sins Are Threefold': Typologies of Bestiality, Masturbation, and Homosexuality in Sweden, 1880-1950." Journal of the History of Sexuality 9, no. 3 (2000), 240-76.

Sandblad, Henrik. Olympia och Valhalla: Idéhistoriska aspekter av den moderna idrottsrörelsens framväxt. Stockholm: Almqvist \& Wiksell international, 1985.

Santesson, Anton B. Handbok i pädagogisk gymnastik för gymnasier och skolor. Karlstad: s.n., 1856.

Santesson, Anton B. Folkskolans gymnastik. Carlstad: s.n., 1859.

Santesson, Anton B. Folkskolans gymnastik och vapenföring. Carlstad: Agne Peterssons förlag, 1864.

Santesson, Anton B. “Gymnastik för unga qvinnor och skolflickor.” Svenska gymnastik-föreningens tidskrift 1, no. 1 (1865a), 127-30.

Santesson, Anton B. "Om elementarläroverkens gymnastikmönstring samt skolgymnastikens bedömande af svenska läkaresällskapet." Svenska gymnastik-föreningens tidskrift 1, no. 1 (1865b), 112-16.

Santesson, Anton B. Gymnastik för unga qvinnor och skolflickor. Stockholm: Bonnier, 1866 a.

Santesson, Anton B. “Gymnastik för unga qvinnor och skolflickor.” Svenska gymnastik-föreningens tidskrift 2, no. 1 (1866b), 81-83.

Santesson, Anton B. “Sedeförderfvet i skolorna." Svenska gymnastik-föreningens tidskrift 2, no. 1 (1866c), 72-81.

Santesson, Anton B. Skol-gymnastik för rikets elementar-läroverk: Jemte en kort skildring af disciplinens tillstånd vid flera af dessa läroverk. Stockholm: Bonnier, 1866d. 
Santesson, Gunnar O. C. H. Släkten Santesson från Långaryd. Karlshamn: Lagerblads tryckeri, 1982.

Scott, Joan W. "Gender: A Useful Category of Historical Analysis." The American Historical Review 91, no. 5 (1986), 1053-75.

Sjöstrand, Wilhelm. Pedagogikens historia III:2: Utvecklingen i Sverige under tiden 1805-1920. Lund: Gleerup, 1965.

Smeyers, Paul and Marc Depaepe, eds. Educational Research: The Educationalization of Social Problems. Dordrecht: Springer Netherlands, 2008.

Svalling, Ester. "Den kvinnliga avdelningen vid Kungl. gymnastiska centralinstitutet 1864-1913." In Kungl. gymnastiska centralinstitutets historia 1813-1913, 24969. Stockholm: P. A. Norstedt \& söner, 1913.

Svenskt biografiskt lexikon. Stockholm. http://riksarkivet.se/sbl

Terret, Theirry and Leomar Tesche. "French Gymnastics in Brazil: Dissemination, Diffusion and Relocalization." In Gymnastics: A Transatlantic Movement, edited by Gertrud Pfister, 95-110. London: Routledge, 2014.

Trangback, Else. "Discipline and Emancipation Through Sport." Scandinavian Journal of History 21, no. 2 (1996), 121-34.

Tröhler, Daniel. Pestalozzi and the Educationalization of the World. Basingstoke: Palgrave Macmillan, 2013.

Turner, Bryan S. Regulating Bodies: Essays in Medical Sociology. London: Routledge, 1992.

Weber, Eugen. Peasants into Frenchmen: The Modernization of Rural France, 18701914. Stanford: Stanford University Press, 1976.

Wenk, Silke. "Gendered Representations of the Nation's Past and Future." In Gendered Nations: Nationalisms and Gender Order in the Long Nineteenth Century, edited by Ida Blom, Karen Hagemann and Catherine Hall, 63-77. Oxford: Berg, 2000 .

Vertinsky, Patricia. The Eternally Wounded Woman: Women, Doctors, and Exercise in the late Nineteenth Century. Urbana: University of Illinois Press, 1994.

Westberg, Johannes. Att bygga ett skolväsende: Folkskolans förutsättningar och framväxt 1840-1900. Lund: Nordic Academic Press, 2014.

Yttergren, Leif and Hans Bolling. "Kvinnor, karriär och familj: En studie av svenska kvinnliga gymnastikdirektörers yrkeskarriärer och livsöden kring sekelskiftet 1900." Historisk tidskrift 136, no. 2 (2016), 185-219. 